\title{
Snip-Snap: An Analysis of Interpersonal Meanings in a Political TV Interview
}

\author{
Kun-zhen Huang ${ }^{1}$ \\ ${ }^{1}$ School of Foreign Languages, Guangdong Pharmaceutical University, China \\ Correspondence: Kun-zhen Huang, School of Foreign Languages, Guangdong Pharmaceutical University, \\ 510006, Guangzhou, China. Tel: 86-132-2945-0103. E-mail: Pan_lbo@126.com
}

Received: July 4, 2014 Accepted: August 15, 2014 Online Published: October 1, 2014

doi:10.5539/ijel.v4n5p89 URL: http://dx.doi.org/10.5539/ijel.v4n5p89

\begin{abstract}
This paper mainly employs Halliday's Systemic Functional Grammar theory, concerning the interpersonal metafunction, to make a theoretically founded analysis on an episode in Feng Yun Dui Hua, a famous television program from Phoenix TV. The specific data is from an interview between the TV host Ruan Cishan and the contemporary US Secretary of State Colin Luther Powell. Through analysis of interpersonal meanings in the interview discourse, it is revealed that Mood, modality, person pronouns and Appraisal system are all important devices to reveal the features of the political TV interview.
\end{abstract}

Keywords: Systemic Functional Grammar, interpersonal metafunction, political TV interview

\section{Introduction}

Systemic Functional Grammar (hereinafter SFG), constructed by M.A.K Halliday in the late $20^{\text {th }}$ century, has played an important role in Discourse Analysis (hereinafter DA) and provided us with new and effective insights into it. As Halliday himself puts it, the SFG constructed to serve the text analysis, which is sensible and useful for any spoken or written text in modern English (Halliday, 1994/2000: F41).

A political interview usually involves two parties in the conversation, the host and the visiting guest. As the addresser, the first mission for the host is to attain information from the visiting guest through different questions. And as the addressee, the party to give information, the visiting guest usually chooses cautious wordings towards the sensitive issues, especially those with disputes.

Since no detailed studies have been intended to analyze the spoken text of political interview and Halliday's SFG theory is considered as a workable frame in DA, therefore, exploring how interpersonal function is realized in the conversation between host and guest by employing Halliday's linguistic model and Martin's Theory as the analytical framework becomes the motivation of this paper.

\section{Literature Review}

The SFG theory constructed by M.A.K Halliday in the $20^{\text {th }}$ century is one of the most important linguistic theory in the world today, and the foundational contributions made by lots of modern linguists to the development of this theory is worthy of being mentioned. The interpersonal meaning of language has long been an object of study by many linguists, among whom the functionalists take the lead. Halliday (1985) points out that the interpersonal metafunction carries a heavy semantic load and its lexicon-grammatical resources are those of Mood and associated pattern of modality, intensification and other evaluation devices realized prosodically throughout the text. Also, according to Halliday (2000), the interpersonal metafunction concerns how the language to realize the dynamic meaning of the language to show the relationship between the speaker and the hearer, and how to use language to express one's attitude and to influence the hearers. Social groups are delimited via this function and the individual is identified and reinforced by enabling the speaker to interact with others. Representatives aboard who apply interpersonal function on studies are Martinet (1960) on broadcast interviews with politicians, Leech (1966) and Cook (1992) on advertising English, Coates (1983) on semantics of the modal auxiliaries, Thibault (1986) on gender and ideology from radio broadcasts and advice columns in Australian, Threadgold (1988) on genre and discourse in theatrical rehearsal and performance, Martin (1992) on micro-proposals and macro-propositions, Lemke (1992) on discourse resources, Bybee (1995) on Modality in grammar and discourse, and Gregory (2003) on pragmatic theory and information construction as well. It is 
worthy of being mentioned that the Appraisal theory constructed by Martin (2003) is the most noteworthy investigation of interpersonal meaning.

In China, the study about interpersonal metafunction gains its popularity later than the other two metafunctions. In recent years, lots of Chinese scholars made researches on the interpersonal meaning, like $\mathrm{Hu}$ (1990) on the mood system of Chinese, Zhang (1998) on the scope of the mode and expression, $\mathrm{Li}$ (2000) on the five linguistic devices, etc. One representative scholar is Huang (2001), who studied the commercial advertising text from the perspective of interpersonal function and he also further adopted SFG to analyze the interpersonal meaning of the six versions of English translations of Chinese poem.

\section{Data and Methodology}

The specific material is a spoken text selected from an episode in Feng Yun Dui Hua, the interview between Mr. Ruan Cishan and US Secretary of State Colin Luther Powell. The reasons for choosing the data are as follows: (1) The program itself mainly focuses on the international events, especially those with disputes. In the process of interviews, when facing those crucial political figures from all over the world, the TV host Ruan Cishan usually tends to uncover the profound meanings behind the global issues through questions that seem uncomplicated. The witty and tactful interaction between the host and visiting guests leaves the audience a deep impression. (2) The specific discourse is from the episode on Oct $24^{\text {th }}, 2004$. At that time, Mr. Ruan Cishan interviewed Colin Luther Powell with regard to Taiwan issue, Six-Party Peace Talks, and so forth. In the course of that, Mr. Ruan Cishan successfully made Colin Luther Powell give up the ambiguity on the One China Policy that US habitually practices and clearly stated that "Taiwan is not independent; it does not enjoy sovereignty as a nation" (Ruan, 2004). The interview caused waves around the contemporary political field in Taiwan, and economic fluctuation as well. It is called a historic conversation among all the political interviews. Due to the limited space in this paper, the original text of this interview would be omitted and the specific details of the spoken text should be referred to the related publication of Feng Yun Dui Hua by Ruan Cishan in 2004.

There are two research questions in this paper: (1) How was the interpersonal meanings realized through Mood and person pronouns? (2) How did the host and guest employ modality and Appraisal System in their questions and answers to convey the information? The research questions will be answered at the end of the paper.

\section{Analysis of the Interview}

The discussion in this section will concentrate on Mood, modality, person pronouns and Appraisal resources.

\subsection{Mood Analysis}

In Halliday's SFG theory, giving and demanding are two speech roles and the things that are exchanged may be information or goods/services. There are four speech functions when the two variables are taken together: offer, command, statement and question.

The Mood system is made up by Subject and Finite, which together play a vital role in carrying out the interpersonal function of a clause through different types of interact: interrogative, declarative, imperative and exclamative as well. Therefore, through the analysis of the Subject and Finite, the speech roles and relationship between the speaker and listener will be revealed and how the language expresses the interpersonal meanings through the grammatical resources will also be understood. During the process of conversation, the TV host Ruan Cishan interviewed Colin Luther Powell with regard to three main issues, which are US-China relationship, Taiwan issues and Six-Party Peace Talks. The host asked information for nine times, involving eleven questions. When asking a question, the TV host takes on the role of information seeker and requires the guest to take on the role of a supplier of the information demanded. Through this way, the two fundamental speech roles in any exchange are giving and demanding a commodity of some kind. The commodity here is information and if the exchange is successful, the guest receives the information the host provides and questions will be answered.

From the questions that Ruan Cishan asked, it can be seen that there is a fixed pattern for Ruan Cishan to ask for information from Colin Luther Powell. First, the statements are naturally expressed through the declarative clauses by him to give information about the following questions he wanted to ask, such as (Ruan, 2004):

a. Recently, one statement from Taiwan.....Say, if China attacks us, we'll attack Shanghai .........

b. Recently ....... Taiwan keeps on saying that "........ we are already independent country with sovereignty

From the nine times for Ruan Cishan demanding information from Colin Luther Powell, he employed the declarative Mood before his asking every single time, to describe the contemporary situation that relates to the following questions. By each declarative Mood, Ruan Cishan conveyed information to Colin Luther Powell and 
provided the topics. And then, Ruan Cishan asked eleven concrete questions to attain information from Colin Luther Powell. Among these eleven questions, five of them are yes/no interrogatives and the rest six are all WH-interrogatives. In yes/no interrogatives, it is primarily the polarity of the message which the speaker wants the listener to specify, while in WH-interrogatives, the speaker is demanding the listener fill in a missing part of the message (Thompson, 2000:47). In order to illustrate the frequency of yes/no interrogative and WH-interrogative that relate to this three major issues, the following table will be made:

Table 1. Frequencies of different types of interrogatives in three major issues

\begin{tabular}{lll}
\hline Three major issues & Yes/no interrogatives & WH-interrogatives \\
\hline US-China relationship & 2 & 2 \\
Taiwan issues & 2 & 3 \\
Six-Party Peace Talks & 0 & 19 \\
\hline
\end{tabular}

From the table 1, it can be seen that Ruan Cishan attached more importance to US-China relationship and Taiwan issues than the Six-Party Peace Talks. He tried to employ both yes/no interrogatives and WH-interrogatives to define the scope for Colin Luther Powell answering and attained a more specific information he wanted.

Take the Taiwan issues as an example, Ruan Cishan first stated a fact that Colin Luther Powell has talked to President Hu that morning and began to ask him questions about the Taiwan issues. Ruan Cishan first used a yes/no interrogatives "did you talk about the US weapons sales to Taiwan" (Ruan, 2004) to start the topic. By raising this yes/no interrogative clause, Ruan Cishan clearly carried out his purpose, which indicated that he wanted to talk about Taiwan and according to the question type he employed, Colin Luther Powell had to specify the message he got, which means "they did talk or they did not talk" (Ruan, 2004). And in the next question, Ruan Cishan again expressed a statement from Tainwan, which makes Chinese assume that US is going to provide the technology to develop medium range missiles to Taiwan. And then, Ruan Cishan again raised a yes/no interrogatives "is that the case?" (Ruan, 2004). Through this question, being different from the WH-element question which provides listener more choices to express ambiguity, Colin Luther Powell only had one choice, "yes" or "no", which would clearly state the attitude of US government towards the high-tech weapons sales to Taiwan.

After that, Ruan Cishan kept stating that recently Taiwan said that they don't need to declare independence because they are already independent country with the sovereignty and because there are already some twenty-six countries that recognize them. At this time, Ruan Cishan did not ask Colin Luther Powell with the yes/no interrogatives any more. Instead, he applied a WH-element interrogative and asked what does this kind of statement that comes from Taiwan mean to him. To answer this question, Colin Luther Powell could no longer simply answer yes or no, but had to tell Ruan Cishan and the audience in front of the TV that what exactly this kind of statement means to him. He had to state that how does he and his government think about this sort of statement, whether it is good or bad, and the reasons that made they think so. It is clear that at this time, WH-interrogatives are more open and can acquire more information from the quest. After Colin Luther Powell's expressed his opinions about the nervous statement from Taiwan, Ruan Cishan continued his pursuit of US government's attitude towards Taiwan issues and again asked that what does Colin Luther Powell want to make more clear on the insistence on a kind of ambiguity on the One China Policy, which pushed him to make a further step on the explanation about the statement from Taiwan. Finally, Ruan Cishan quoted a way of saying by the former president Mr. Jiang about the missile deployment and made a assumption with a yes/no interrogatives, which presumed that if China reduce the missiles aiming at Taiwan, is the US going to cancel or at least consider twice selling weapons to Taiwan? For the last time when asking question about the Taiwan issue, this yes/no interrogative again limit the scope for Colin Luther Powell to answer and demanded his clear answers at the most.

Therefore, it can be indicated that the TV host tends to employ two main types of Mood in the conversation: declarative Mood and interrogative Mood. The former one is often used by the TV host to give information about the topics he wants to talk and also enable the host to provide the background about episode, including the time, place, figures and events, which would help the audience achieve a better understanding about the contemporary situation. The latter one is applied to demand information or action from the guest. It is worth noting that since the political TV interview is quite serious and formal, the other two types of Mood, imperative and exclamative, seldom appear in the course of conversation, which may be considered as being crude and rash. 


\subsection{Modality Analysis}

According to Halliday (1994/2000), the modality system can be divided into two types, one is modalisation, for negotiating information, and the other is modulation, for negotiating services. Modality carries the burden of a clause as an interactive event and it is regarded as one of the main ways to realize the interpersonal meanings. The attitude expressed by the speaker falls into the area of validity, which means the speaker may signal a higher or lower degree of certainty about the validity of proposition, or a higher or lower degree of pressure on the other on for executing a command.

The modal commitment is realized through the finite modal operator and the modal adjunct. Finite modal operators usually include may, might, must, will, shall, should, which are called modal auxiliaries in the traditional grammar. While the modal adjunct can be divided into comment adjunct and Mood adjunct, including words like possible, usually, certainly, never, etc. Totally there are 20 modal operators used by Colin Luther Powell to convey the information during his 9 answers. The frequencies of the modal operators are applied differently in three major issues. When answering the questions about US-China relationship, Colin Luther Powell employed three modal operators, which are can, should and might, each for just one time. When talking about the Taiwan issues, the numbers and frequencies of the modal operator both increased. Being different from the US-China relationship, there are 7 modal operators in this part, which are would, should, will, can, could, often and might. And together, the frequencies of these seven operators are 14. For probability, would occurs three times, will three times, can one time and might one time. For obligation, should appears five times. And for usuality, often exists one time. Finally, when mentioning the Six-Party Peace Talks, Colin Luther Powell again applied three operators, which are should, can and will, each for one time. In the course of answering questions, it can be noticed that the finite modal operator should are found to occur with the highest frequencies, totally seven times, can, as well as would with three times, might with two times and could with one time. There is only one modal adjunct, often, in Colin Luther Powell's answer, and it just occurs for one time.

It is clear that among the three aspects that Colin Luther Powell talked about, he attached more importance to the Taiwan issue, for the length of his coverage in this part and the frequencies of modal operators he used in this section, which indicated his commitment to the validity of what he said. Referring to the original text of the conversation, Colin Luther Powell gave all his answers to the questions from Ruan Cishan. There are only four sentences with modal operators in Colin Luther Powell's answers about the US-China relationship and Six-party Peace Talks, which are listed as follows (Ruan, 2004):

a. so we can understand .........

b. ........ all of us should be active participants.

c. ......... they can reach the United States.

d. And benefits will flow

Considering the can is untypical of the modal operators and it is near to the meaning of the ordinary words that express the ability of the subject (Halliday, 1994/2000:359), it can be concluded that there are only four modal operators occur in the 38 sentences about the above two aspects that Colin Luther Powell discussed. The rest part of his answers are all expressed in polarity, which indicates that he is quite sure about the information he gave to Ruan Cishan.

But the situation is different while the topic shifted to the aspect of Taiwan issues. Among 36 sentences that Colin Luther Powell gave Ruan Cishan to answer his questions, there are seven modal operators together occurs 14 times in this part. And the effect of the sentences that includes these modal operators can be divided into three types (Ruan, 2004):

(1) To be respectful

In this case, the modal operators occurred can make the speaker's attitude remote

from the statement and also can show the speaker's respect to the listeners, such as :

a. And our response is that they should not ......

b. ........ it is a policy that should be..... and should remain.....an will remain.........

It can be seen that basically Colin Luther Powell employed should and will in his answers. These two words are modal operators with median to high degree of modal commitment and they express the speaker's great confidence in what he believes will happen in the future. By applying these words, Colin Luther Powell revealed that the US government had recognized the benefit of One-China Policy and did not support any independence 
movements from Taiwan. From his point of view, both China and Taiwan should restrain and look for ways of improving dialogue to solve the disputes. However, making suggestions to China's internal affairs is always a sensitive issue to the Chinese public. So in this kind of situation, employing modal operators with median to high degree makes his comments appear to be more pertinent than word with a high degree, such as must. Colin Luther Powell here mitigated his speech power by making suggestions with modal operators without creating offense to the audience.

(2) To protect the speaker himself

In this case, the modal operators that appear in the sentences contain rich meaning of modality. They indicate that words in speaker's expression are part of his psychological process, and therefore, the speaker does not need to take full responsibility for it (Gregory, 2003). For example (Ruan, 2004):

a. It would be inconsistent

b. It's often .......mbiguous but ........

It can be noticed that Colin Luther Powell generally applied modal operators with median to low degree. When the interview started relating to Taiwan affairs, Ruan Cishan first quoted a nervous statement from Taiwan and asked if it was a hint that the US government may provide technology for Taiwan to develop median range missiles. And Ruan Cishan kept asking what the "independence declaration" from Taiwan meant to Colin Luther Powell. Through the usage of modal words with median to low degree, such as would, Colin Luther Powell could shield himself from full commitment to the truth value of his assertion. His answers to Ruan's questions actually indicated that the US government understood that China does not appreciate the US weapon sales to Taiwan and the US government would only provide Taiwan with the technology that ensured their self-defense, and meanwhile, implied that the US government would still continue the weapon sales action and the only thing they admit was they did not support independence announced by Taiwan. However, by using the modal operators in the above examples, it helps to reduce the force of the statement and consequently prevents the speaker from possible objection from the public.

(3) To convey the tentative tone

The political interview is an occasion for highlighting self-image, and since it will

always relate to events with disputes, the modal operator will be used by politicians to convey a tentative tone (Coates, 1983; Bybee, 1995). Examples can be seen from the following sentence (Ruan, 2004):

a. .......... so that they could pursue their development.

b. ........... and military steps they might be taking .......

With the modal operators in the example, Colin Luther Powell expressed his views subjectively but implicitly. He implied that China should accept the fact about US weapons sales to Taiwan and do not take any action towards it, or else it would cause imbalance about the military status between mainland and Taiwan, and that would make US government keeps selling weapons to Taiwan and finally caused the vicious circle. And if China accept the current situation, all the nations in the Asia-Pacific region will get the benefits. By expressing the above idea, with the modal operators, Colin Luther Powell asserted his views in a more tentative way so as to avoid possible challenges.

\subsection{Person Pronouns Analysis}

Generally, the use of person pronouns is to establish a good relationship between the

speaker and listener. Ruan Cishan and Colin Luther Powell both employed lots of person pronouns, including the first person pronouns, the second person pronouns, the

third person pronouns, names and titles as well. The specific functions of the above different sorts of person pronouns in the interview can be divided as follows (Ruan, 2004):

(1) To shorten the distance between speaker and listener

Expect for attracting the listener's attention, the employment of person pronouns

can also activate and strengthen the relationship between them. For example:

a. $\boldsymbol{I}$ think $\boldsymbol{w e}$ have .......... We have ......... We are ..........

b. .......... We have ...... But what we decided to ..... is not to ...... so we can ........

The pronouns $I$, we above shorten the distance between the speaker and listener. It 
gives the listener the impression that the speaker cares for them, and by doing so, the speaker induces the listener to engage in the discourse, which helps establish an interactive relationship between them.

(2) To improve the speaker's will upon the listener

According to Sultan (1996), the proper use of inclusive personal pronouns makes

it possible for the speaker to appeal to the listener so as to create a congenial relationship between them and at the time, the speaker advertises his own opinions too. Such examples can be found in the discourse again, in terms of we, and they are used by the speaker to show his positive politeness and include the listener in the activity. Examples are as follows (Ruan, 2004):

a. ..but we have to ..........And what we try to do ..But what we have......

From the above sentences, it can be seen that through the employment of we, the

speaker mitigated his imperative tone. And in this way, the speaker expressed something that he considered as obligatory and could succeed in imposing his will upon the others.

(3) To convey information

During the interactions between speaker and listener, they can address others not only by person pronouns, but also by proper names and names with titles. The third person pronouns, names and titles in this discourse are generally used to convey information.

By employing these, the speaker can impress the listener with kindness and amicability, and the listener will naturally play a cooperative and active role in the interaction. For example (Ruan, 2004):

\section{a. Mr. Secretary............ \\ b. .........with President $\mathrm{Hu}$....... \\ c. ......President Bush and Mr. Kerry should ..... but candidate Kerry, Senator Kerry....... \\ 4.4 Realization through Appraisal Resources}

Martin's Appraisal theory extends the scope of the interpersonal metafunction research of SFG. By telling listeners how they feel about things and people, the speakers succeed in negotiating their social relationships through using the resource of Appraisal. The realization of interpersonal meanings of Appraisal resources will be explored in the following parts.

\subsubsection{Engagement: Monogloss and Heterogloss}

In the TV interview, the TV host and guest have to find a good way of communication and exchange information from each other, thus it is difficult to achieve the analysis of monogloss, as it indicates the source is simply one voice while the TV interview demands at least two voices in the course of the interview. Therefore, considering the genre of the discourse, the analysis of monogloss will be ignored and attention will be paid on the heterogloss part. Since the modality has been specifically explored before, the following discussion will only focus on projection and concession.

In the process of interviews, it is common that people quote or report what they say or think and this type of linguistic resource is called projection. During the conversation between Ruan Cishan and Colin Luther Powell, it can be found that projection is employed mostly by Ruan Cishan to define the topic that he wanted to talk with Colin Luther Powell. For example (Ruan, 2004):

a. ......one statement from Taiwan .... Say, if China attacks us, we'll attack Shanghai; from Shanghai to Taiwan you need a medium range missile.......

b. ......Taiwan keeps on saying that ".... we are already independent country with the sovereignty because ......"

The TV host Ruan Cishan quoted both the exact words and general meanings from the Taiwan local government, to retell their attitude towards the declaration of independence and ask for Colin Luther Powell's opinion as well. By the application of projection, Ruan Cishan successfully started a new topic and fixed it up in terms of the concrete events, which implicitly assign responsibility to Colin Luther Powell to express his opinions.

Being different from projection, concession is another resource in heterogloss, which is also known as counter expectancy. Usually, the word but is the most common conjunction for signaling concession, and lots of examples can be found in the data of this dissertation (Ruan, 2004):

a. .......But what we .....is not to ignore that disagreement, $\boldsymbol{b u t}$ to once again .......

b. .......But we have made it very clear..... 
c. …...... but our policy is clear.

d. ...........but I think it's pretty clear.

So it can be inferred from the above sentences that Colin Luther Powell used the word "but" to monitor the listener's expectations. That is, although the US and China have disagreements towards lots of issues, the attitude of US government is clear and firm, which means they do not admit any declaration of independence from Taiwan and do not appreciate any deliberate provocation from Taiwan.

\subsubsection{Attitude: Effect, Judgment and Appreciation}

In the TV interview, both the host and guest tend to share emotions, pass judgment and give valuation about relevant people, things and states of affairs as well. Therefore, attitude is a key point to realize the interpersonal meanings, which comprises affect, judgment and appreciation, three major regions of feelings.

Considering the genre of the interview, it can be seen that the TV host, Ruan Cishan, was responsible for raising questions, while the guest, Colin Luther Powell answered. Therefore, in the process of analyzing the realization of attitude, the attention will be focused on Colin Luther Powell's answers towards different questions. For the three major aspects occurred in the interview, Colin Luther Powell showed different kinds of attitude. The specific details for reference are as follows (Ruan, 2004):

US-China relationship:

Table 2. Attitudes shown by Colin Luther Powell in US-China relationship

\begin{tabular}{|c|c|}
\hline Affect & $\begin{array}{l}\text { Very comfortable. } \\
\text {.... very impressed at the smoothness with..... }\end{array}$ \\
\hline Judgment & ------------------------- \\
\hline Appreciation & $\begin{array}{l}\text {........such an improvement in the relationship..... } \\
\ldots . . . \text { a very close relationship...... a real success. } \\
\ldots . . . \text { One China Policy is sound; .... benefited all the parties..... It rests solidly on ....... }\end{array}$ \\
\hline
\end{tabular}

Taiwan issues:

Table 3. Attitudes shown by Colin Luther Powell in Taiwan issues

\begin{tabular}{ll}
\hline Affect & .......this kind of rhetoric is unfortunate...... \\
\hline Judgment & -----------.------- \\
\hline \multirow{2}{*}{ Appreciation } & remains .... our firm policy. \\
& .........The president has reaffirmed ....... \\
\hline
\end{tabular}

Six-Party Peace Talks:

Table 4. Attitudes shown by Colin Luther Powell in Six-Party Peace Talks

\begin{tabular}{|c|c|}
\hline Affect & 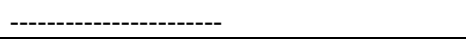 \\
\hline Judgment & 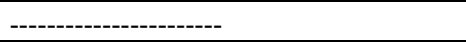 \\
\hline Appreciation & $\begin{array}{l}\text {.......a very important role in helping....... } \\
\text {....... im important role to play. }\end{array}$ \\
\hline
\end{tabular}

From the above examples, it can be noticed that Colin Luther Powell gave positive words like improvement, comfortable, impressed, smoothness, close, success in his answers to US-China relationship, which indicates that he and the government he's on behalf of was quite satisfied with the contemporary situation between USA and China. And for the Taiwan issue, answers are different. When talking about the attitude from the US government towards One China Policy, Colin Luther Powell used positive words, such as sound, benefited, solidly, firm and reaffirmed, to tell the listener that he wanted to make it clear that there is no ambiguity on the One China Policy and they did respect the Three Communiques. Moreover, when Ruan Cishan asked what is his opinions about the expression from Taiwan local government, which declared that Taiwan is already an independent country, Colin Luther Powell applied negative words like unfortunate, tension, to show his inappreciation about this kinds of declaration. And finally, when mentioning the role of China in the Six-Party Peace Talks, Colin Luther Powell 
said "important" for twice to express his comments on this event.

\subsubsection{Graduation: Force and Focus}

During the course of conversation, the speaker can say how he feels about someone or something with gradable attitudes. According to Martin (2000:42), words that intensify meanings such as very/really/extremely and vocabulary items include degrees of intensify such as happy/delighted/ecstatic, can be referred as force. And words involve sharpening or softening categories of people and things, such as about, exactly, kind of or sort of, can be referred as focus.

In the discourse, it is very common to find the force resources, for the speaker to intensify his meanings, and the application of focus is relatively less. For example (Ruan, 2004):

a. …... but I think it's pretty clear.

b. Very comfortable.....

c. Oh, absolutely (I have).

The above sentences are said by Colin Luther Powell when answering questions. It can be observed that both force and focus resources occurred in his words, which helped him express how he felt about the Chinese leader and One China Policy. The employment of these resources made Powell's words with high grading, and finally constructed a very good atmosphere for the communication between he and Ruan Cishan.

\section{Conclusion}

The analysis of the data has yielded the following major findings: (1) It is found that the TV host paid much attention to the employment of declarative clause, which helped him give information about the topic he wanted to start, and after that, he adequately used yes/no interrogatives and WH-interrogatives to define the scope for the host to answer those questions, in order to get the exact information he wanted. The exclamative and imperative clauses never occurred in the course of conversation, which is useless for constructing a good atmosphere for communication between the host and guest. (2) It is revealed that the choices of modal operators with different degree of value agree with the communicative purposes of the speaker. (3) It is also shown that person pronouns establish a good relationship between the host and guest, successfully shortening their distance as well as helping the speaker to advertise his opinions, and even impose his will upon the listeners implicitly.

The analysis also reveals that the linguistic choices, in terms of Mood, modality, person pronouns and Appraisal system, can contribute to the realization of interpersonal functions in the process of conversation, which may be of a certain value in achieving a better understanding towards the functional features of this kind of genre.

\section{References}

Bybee, J., \& Fleischman, S. (1995). Modality in Grammar and Discourse. http://dx.doi.org/10.1075/tsl.32

Coates, J. (1983). The Semantics of the Modal Auxiliaries. London: Croom Helm.

Cook, G. (1992). The Discourse of Advertising. London: Routledge.

Gregory, W., Betty, J. B., \& Jeffrey, P. K. (2003). A Pragmatic Analysis of the Epistemic Would Construction in English. In R. Facchinetti, M. Krug, \& F. Palmer (Eds.), Modality in Contemporary English (pp. 71-79). Berlin/New York: Mouton de Gruyter.

Halliday, M. A. K. (1985). An Introduction to Functional Grammar. London: Arnold.

Halliday, M. A. K. (1994/2000). An Introduction to Functional Grammar (2nd ed.). London: Edward Arnold/Beijing: Foreign Language Teaching and Research Press.

Hu, Z. L. (1990). Language System and Function. Beijing: Peking University Press.

Huang, G. W. (2001). Theory and Practice of Discourse Analysis: A Study in Advertising Discourse. Shanghai: Shanghai Foreign Language Education Press.

Leech, G. N. (1966). English in advertising: A linguistic study of advertising in Great Britain. London: Longman.

Lemke, J. (1992). Interpersonal meaning in discourse: value orientation. In M. Davis \& L. Ravelli (Eds.), Advances in Systemic Linguistics: Recent Theory and Practice. London: Pinter.

Li, Z. Z. (2000). Coming to Grips with Interpersonal Meaning in Autobiography. Beijing: Junshi Yiwen Press.

Martin, J. R. (1992). English Text: System and Structure. http://dx.doi.org/10.1075/z.59 
Martin, J. R. (2000). Beyond exchange: Appraisal systems in English. In S. Hunston \& G. Thompson (Eds.), Evaluation in Text: Authorial Stance and the Construction of Discourse (pp. 147-175). Oxford: Oxford University Press.

Martin, J. R., \& Rose, D. (2003). Working with Discourse: meaning beyond the clause. London: Continuum.

Martinet, A. (1960). Éléments de linguistique générale. Paris: Armand Colin.

Ruan, C. S. (2004). Feng Yun Dui Hua. Beijing: World Knowledge Press.

Thibault, P. J. (1986). Text, Discourse and Context: a social semiotic perspective. Toronto Semiotic Circle, 3 , $26-42$.

Thompson, G. (1996/2000). Introduction Functional Grammar. London: Edward Arnold/Beijing: Foreign Language Teaching and Research Press.

Threadgold, T. (1988). The Genre Debate. Southern Review, 21(3), 15-330.

Zhang, D. L. (1998). Functional Stylistics. Jinan: Shangdong Education Press.

\section{Appendix}

Q: Mr. Secretary, before you leave for China, you accept media interviews saying you are very proud of the US-China relationship because it is based on the mutual respect of each other's needs. After you met with President Hu early this morning, do you still have this proud sense?

A: Oh, absolutely. I think we have seen such an improvement in the relationship over the four years. We have resolved some of areas of disagreement on trade and economic activities. We are working so closely to try to solve the problems of North Korean nuclear weapons. All of our ministers in the United States meet on such a frequent basis with Chinese ministers. Our two presidents, President Hu and President Bush, have a very close relationship, and so I think that this is a real success, how we have gone from a confrontation in the early April 2001, when our planes collided, to the point now where are cooperating in so many areas. This doesn't mean that there are no disagreements. There are disagreements. We have a disagreement with respect to human rights behavior. But what we decided to do today, for example, is not to ignore that disagreement, but to once again begin the process of resuming a dialogue so we can understand each other's positions better. This is what two mature countries do when they want to be friends and they want to be partners, and that is what we are doing with China.

Q: So this morning when you talked to Mr.Hu, did you talk about the U.S Weapons sales to Taiwan and what was his response?

A: Well, they would prefer that we not sell weapons to Taiwan, and they made that clear to me, as they have in the past. And our response is that they should not view this as any lack of interest on our part in our One China Policy. In fact, our One China Policy is sound. It has benefited all the parties for so many years. It rests solidly on the Three Communiques that under grid the One China Policy. But at the same time, we have an obligation under our law to make sure that Taiwan has the means to defend itself, self-defense, not attacking anybody, but self-defense. And in order to meet that obligation we have under our law, form time to time arms sales are appropriate to Taiwan. We encourage the Chinese side to very careful about the deployments that they make across the straits, which might raise the concern in Taiwan, thereby generating a requirement for more weapons sales. So both sides should restraint, not take any unilateral actions, look for ways of improving dialogue across the straits and move forward that day when we will see a peaceful unification.

Q: Recently, one statement from Taiwan makes Chinese nervous. (Inaudible)......say, if China attack us, we'll attack Shanghai; from Shanghai to Taiwan you need a medium range missile. And the Chinese think this is a hint that the US is going to provide the technology to develop medium range missiles. Is that the case?

A: No. The only technology we are providing to Taiwan, if they choose to buy it, is technology that will allow for their self-defense. We don't want them to have an offensive capability. We also think that this kind of rhetoric is unfortunate; it just raises tensions. And it all relates to the feelings in some parts, or of some in Taiwan, that they should move toward independence. But we have made it very clearly to all parties, to the authorities in Taiwan and to the authorities in Beijing, that the United States does not support independence for Taiwan. It would be inconsistent with our One China Policy.

Q: Recently the Chinese feel a touch bit of nervous. Taiwan keep on saying that "we don't need to declare independence because we are already independent country with the sovereignty because there are already some 
twenty-six countries that recognize us, so many countries." What does this mean to you?

A: Well, they can make these sorts of statements but our policy is clear. There is only one China, Taiwan is not independent, it does not enjoy sovereignty as a nation, and that remains our policy, our firm policy. And it is a policy that has allowed Taiwan to develop a very vibrant democratic system, a market economy system and provided great benefits to the people of Taiwan. And that is why we think it is a policy that should be respected and should remain in force and will remain in force, on the American side. It is our policy that clearly rests on Three Communiques. To repeat it one more time: we do not support an independence movement in Taiwan.

Q: So you consider this insistence on a kind of ambiguity on the One China Policy or what do you want to make more clear?

A: It's often conveyed as ambiguous, but I think it's pretty clear. Everyone has understood what it meant for the last thirty years. And it has allowed Taiwan to be successful. And it certainly created conditions of stability and security throughout Asia-Pacific Region. It has allowed China, instead of concerning itself about whether there is going to be conflict with Taiwan, but for China to develop itself and to join the international community, economically and politically. And it has also provided stability for other nations in the Asia-Pacific region so that they could pursue their developments. So our One China Policy is not going to change. The president has reaffirmed this on many occasions. Independence movements or those who speak out for independence movements in Taiwan will find no support from the United States.

Q: You mentioned earlier that you told the Chinese leaders very careful to deploy their missiles or whatever in the other side of Taiwan. I think the former President, Mr.Jiang, when he visited George Bush last year, he also mentioned that if we reduce our missiles aiming at Taiwan, is the United States going to cancel or at least consider twice selling weapons to Taiwan?

A: All of our weapon sales are in the context of what needed to self-defense. And that's the position of the United States government. Now hypothetical offers or ideas that come out are interesting, but we have to look at the reality on the ground. And what we try to do is to ensure that Taiwan is able to defend itself, and that's the basis of our arm sales policy to them. But what we have been seen on the Chinese side is that there has been steady built-up across the Taiwan straits on the Mainland. And the Chinese leaders who I spoke to today said that that's an internal matter for us to determine, for us to decide. I appreciate that position, but nevertheless, that build-up, creates a degree of tension and instability across the straits and puts pressure on the Taiwan side to seek to their self-defense needs. And that's why we continue to point out to Chinese side, that their deployments and military steps they might be taking in mainland are causing an imbalance that requires that imbalance be adjusted in some way and that leads then to additional arm sales.

Q: Mr.Hu just took over the Chairman of the military commission and you are the first U.S high official to meet with him. Do you feel comfortable? What kind of person that you feel he is?

A: Very comfortable. We have known him for a while. I met him on a number of occasions. I have been very impressed at the smoothness with which the transfer of authority of leadership has taken place in China over the last several years. It shows a degree of political maturity. And I think speaks well for the Chinese leadership and the Chinese people. We look forward to working with President $\mathrm{Hu}$ in his new expanded role and capacity.

Q: Before you arrived in Tokyo, you rejected the three-point suggestions from North Korea. Now when you talk to President $\mathrm{Hu}$, what kind of role do you want China to play in the Six-Party peace talks?

A: China has played a very important role in helping to create the Six-Party framework. They have been the host of the meetings, they have been the convener of the meetings and increasingly they have become an active participants; all of us should be active participants. China has an important role to play. It is a neighbor of North Korea. It has considerable influence with North Korea. It provides a great deal of assistance to North Korea. And frankly, when you look at North Korea's nuclear weapons program, who is most immediately threatened by such weapons? Who can those weapons reach? South Korea, Japan, China, Russia-more easily than they can reach the United States. And so we believe that all of North Korea's neighbors have a role to play in persuading the North Koreans to return to the Six-Party framework and to find a solution to the goal that all six parties have, and that is the de-nuclearization of Korean Peninsula. And benefits will flow to North Korea from the de-nuclearization of the Korean Peninsula.

Q: One last question I want to ask you is in this year in the presidential election, is the first year that both parties' candidates did not use the Chinese issue as a major issue. They did not attack each other on the Chinese point of view. Why?

A: Because both sides—President Bush or Mr. Kerry should prevail, but candidate Kerry, Senator Kerry, they 
both understand that we have a good relationship with the Chinese. It is not a matter of contention. Everybody agrees that we have a good relationship with China. That we are working so well in so many areas. Not to say there are not disagreements, but when you hear disagreements form the political parties in my countries now, it has to do with trade imbalance. It no longer has to do with matters of war and peace. It has to do with matters of trade. This is good. This is an improvement. However difficult these trade issues become, these are far better issues to be debating than matters of war and peace, of the kind that we might have been debating twenty years age. And I think this is all to the good for the United States and for China.

Q: Thank you very much Mr. Secretary.

A: Thank you.

\section{Copyrights}

Copyright for this article is retained by the author(s), with first publication rights granted to the journal.

This is an open-access article distributed under the terms and conditions of the Creative Commons Attribution license (http://creativecommons.org/licenses/by/3.0/). 